\title{
Karateristik perawat di Irina F RSUP Prof. Dr. R. D. Kandou Manado yang mengalami keluhan nyeri punggung bawah
}

\author{
${ }^{1}$ Naftalia T. S. Goni \\ ${ }^{2}$ Herlyani Khosama \\ ${ }^{2}$ Melke J. Tumboimbela
}

\author{
${ }^{1}$ Kandidat Skripsi Fakultas Kedokteran Universitas Sam Ratulangi Manado \\ ${ }^{2}$ Bagian Neurologi Fakultas Kedokteran Universitas Sam Ratulangi Manado \\ Email: g.naftalia@yahoo.com
}

\begin{abstract}
Low back pain is a clinical syndrome characterized by major symptoms of pain or other uncomfortable feelings in the lower spine. Low back pain is the leading cause of activity limitation and work absence world-wide. This study aimed to obtain the characteristics of nurses in Irina F Prof. Dr. R. D. Kandou Hospital Manado who had low back pain. This was a prospective descriptive study with a cross sectional design. Samples were 43 respondents. The results showed that of 50 respondents there were 43 respondents who suffered from low back pain. Of 43 respondents there were 14 male nurses (32.5\%), and 29 female nurses (67.5\%). Low back pain was suffered by 16 nurses (37,2\%) aged 23-29 years, 19 nurses (44.2\%) aged 30-39 years, two nurses (4.6\%) aged 40-49 years, and six nurses (14\%) aged 50-57 years. There were 16 nurses (37.2\%) who had worked less than 5 years, and 27 nurses (72.8\%) who had worked more than 5 years. There were seven nurses $(16.3 \%)$ who had working time $<8$ hours a day, and 36 nurses (83.7\%) who had working time $>8$ hours a day.
\end{abstract}

Keywords: low back pain, nurse

\begin{abstract}
Abstrak: Nyeri punggung bawah (NPB) adalah sindroma klinik yang ditandai dengan gejala utama nyeri atau perasaan lain yang tidak enak di daerah tulang punggung bagian bawah. NPB merupakan penyebab utama dari keterbatasan aktivitas dan absen pekerjaan di sebagian besar dunia. Penelitian ini bertujuan untuk mengetahui karakteristik perawat di Irina F RSUP Prof. Dr. R. D. Kandou Manado. Jenis penelitian ini deskriptif prospektif dengan desain potong lintang. Sampel diperoleh sebanyak 43 responden. Hasil penelitian menunjukkan bahwa dari 50 responden terdapat 43 responden (86\%) yang pernah mengalami keluhan NPB. Dari 43 responden terdapat 14 perawat laki-laki (32,5\%) dan 29 perawat perempuan $(67,5 \%)$. NPB dialami oleh 16 perawat $(37,2 \%)$ berusia $23-29$ tahun, 19 perawat $(44,2 \%)$ berusia 30-39 tahun, 2 perawat $(4,6 \%)$ berusia 40-49 tahun, dan 6 perawat (14\%) berusia 50-57 tahun. Terdapat 16 perawat $(37,2 \%)$ yang memiliki masa kerja $<5$ tahun, dan 27 perawat $(62,8 \%)$ memiliki masa kerja $>5$ tahun. Terdapat 7 perawat $(16,3 \%)$ yang memiliki lama kerja $<8$ jam sehari, dan 36 perawat $(83,7 \%)$ memiliki lama kerja $>8$ jam sehari.
\end{abstract}

Kata kunci: nyeri punggung bawah, perawat

Low Back Pain (LBP) atau nyeri punggung bawah adalah sindroma klinik yang ditandai dengan gejala utama nyeri atau perasaan lain yang tidak enak di daerah tulang punggung bagian bawah. ${ }^{1}$ Low Back Pain (LBP) atau yang sering disebut dengan nyeri punggung bawah (NPB) merupakan keluhan yang sering dijumpai. NPB adalah nyeri yang dirasakan di daerah punggung bawah, dapat berupa nyeri lokal maupun nyeri radikular atau keduanya. Nyeri ini terasa di antara sudut iga terbawah dan lipat bokong bawah yaitu di daerah lumbal atau lumbosakral dan sering 
disertai dengan penjalaran nyeri ke arah tungkai dan kaki. ${ }^{2}$

NPB dapat dibedakan menjadi NPB akut dan kronik. Definisinya bervariasi, tetapi gejala yang berlangsung selama lebih dari 12 minggu umumnya disebut sebagai NPB kronik, ${ }^{3}$ dan disebut NPB akut bila gejala berlangsung selama kurang dari enam minggu. Selain NPB akut dan kronik, ada juga yang disebut dengan NPB sub akut yang gejalanya berlangsung selama lebih dari enam minggu dan kurang dari 12 minggu. ${ }^{4}$

NPB adalah penyebab utama dari keterbatasan aktivitas dan absen pekerjaan di sebagian besar dunia yang mengakibatkan beban ekonomi yang tinggi pada individu, keluarga, masyarakat, industri, dan pemerintah.,

Dari hasil penelitian secara nasional yang dilakukan di 14 kota di Indonesia oleh kelompok studi nyeri PERDOSI (Persatuan Dokter Saraf Seluruh Indonesia) tahun 2002 ditemukan 18,13\% penderita nyeri punggung bawah. National Safety Council juga melaporkan bahwa sakit akibat kerja yang frekuensi kejadiannya paling tinggi ialah sakit atau NPB yaitu 22\% dari 1.700 .000 kasus. $^{7}$

Dalam penelitian Engels didapatkan bahwa berdasarkan tinjauan lebih dari 80 makalah tentang NPB pada perawat, setiap tahun angka kejadian NPB di dunia antara 40\%$50 \%$.Sementara itu tinjauan dari berbagai penelitian yang dilakukan di Italia menunjukkan prevalensi NPB dalam waktu 12 bulan antara 33\%-86\% terjadi pada perawat. Prevalensi lebih tinggi dilaporkan bahwa dari penelitian yang dilakukan di Turki didapatkan angka kejadian NPB pada perawat antara $62 \%-88 \%{ }^{8}$

Perawat merupakan tenaga kesehatan yang berhubungan langsung dengan pasien.Salah satu intervensi yang sering dilakukan perawat adalah memobilisasi pasien seperti mengangkat, mendorong, serta memindahkan pasien. Posisi yang salah atau tidak ergonomis dalam melakukan pekerjaan sering menimbulkan ketidaknyamanan, dan kondisi yang sering dikeluhkan adalah NPB. ${ }^{8}$
Manusia dalam menjalankan pekerjaannya dipengaruhi oleh berbagai faktor, ada yang bersifat menguntungkan maupun yang merugikan yang dapat menyebabkan penyakit akibat kerja seperti nyeri punggung bawah. Faktor tersebut antara lain adalah faktor fisiologis, faktor usia, dan faktor aktivitas. ${ }^{8}$

Penelitian ini bertujuan untuk mendapatkan karakteristik perawat di Irina F RSUP Prof. Dr. R. D. Kandou Manado yang mengalami keluhan nyeri punggung bawah.

\section{METODE PENELITIAN}

Jenis penelitian ini ialah deskriptif prospektif dengan desain potong lintang. Penelitian ini dilakukan di Irina F RSUP Prof. Dr. R. D. Kandou pada bulan Januari 2016. Populasi ialah semua perawat di Irina F RSUP Prof. Dr. R. D. Kandou Manado, sedangkan responden ialah perawat yang pernah mengalami keluhan NPB di Irina F RSUP Prof. Dr. R. D. Kandou Manado. Sampel diperoleh dengan teknik nonprobability sampling jenis consecutive sampling. Kriteria inklusi yaitu perawat yang pernah mengalami keluhan NPB dan bersedia menandatangani persetujuan untuk menjadi responden dalam penelitian. Kriteria eksklusi yaitu perawat yang tidak masuk kerja selama penelitian berlangsung. Definisi operasional NPB yaitu suatu rasa nyeri yang dirasakan pada punggung bagian bawah yang bersifat subjektif, diperoleh melalui hasil pengisian kuesioner oleh responden. Data yang diperoleh dari pengisian kuesioner diolah secara manual dan dikomputerisasi serta disajikan dalam bentuk tabel.

\section{HASIL PENELITIAN}

Penelitian dilakukan terhadap 50 perawat yang bekerja di Irina F RSUP Prof. Dr. R. D. Kandou Manado pada bulan Januari 2016; terdapat 43 perawat (86\%) yang pernah mengalami keluhan nyeri punggung bawah.

Tabel 1 memperlihatkan dari 43 perawat yang pernah mengalami keluhan NPB terdapat 14 perawat laki-laki dan 29 
perawat perempuan. Terdapat 16 perawat yang berusia antara 23-29 tahun, 19 perawat berusia antara 30-39 tahun, 2 perawat berusia antara 40-49 tahun, sedangkan 6 perawat berusia antara 50-57 tahun. Terdapat 16 perawat yang telah bekerja selama kurang dari 5 tahun, 27 Tabel 2 memperlihatkan dtahun. Terdapat 7 perawat yang bekerja selama kurang dari 8 jam sehari dan 36 perawat bekerja selama lebih dari 8 jam sehari.

Tabel 1. Karakteristik perawat yag menjadi responden

\begin{tabular}{|c|c|c|c|}
\hline No & $\begin{array}{c}\text { Karakteristik } \\
\text { Perawat }\end{array}$ & Jumlah & $\%$ \\
\hline \multirow[t]{4}{*}{1} & Jenis Kelamin & & \\
\hline & Laki-laki & 14 & 32.5 \\
\hline & Perempuan & 29 & 67.5 \\
\hline & Total & 43 & 100 \\
\hline \multirow[t]{6}{*}{2} & Usia & & \\
\hline & 23 - 29 tahun & 16 & 37.2 \\
\hline & 30 - 39 tahun & 19 & 44.2 \\
\hline & 40 - 49 tahun & 2 & 4.6 \\
\hline & 50 - 57 tahun & 6 & 14 \\
\hline & Total & 43 & 100 \\
\hline \multirow[t]{4}{*}{3} & Masa Kerja & & \\
\hline & $<5$ tahun & 16 & 37.2 \\
\hline & $>5$ tahun & 27 & 62.8 \\
\hline & Total & 43 & 100 \\
\hline \multirow[t]{4}{*}{4} & Lama Kerja & & \\
\hline & $<8$ jam & 7 & 16.3 \\
\hline & > 8 jam & 36 & 83.7 \\
\hline & Total & 43 & 100 \\
\hline
\end{tabular}

Tabel 2. Interpretasi Modified Oswestry Low Back Pain Disability Questionnaire

\begin{tabular}{lcc}
\hline \multicolumn{1}{c}{ Tingkat Disabilitas } & Jumlah & $\%$ \\
\hline $\begin{array}{l}\text { Pembatasan aktivitas } \\
\text { ringan }\end{array}$ & 39 & 90,7 \\
$\begin{array}{l}\text { Pembatasan aktivitas } \\
\text { sedang }\end{array}$ & 4 & 9,3 \\
$\begin{array}{l}\text { Pembatasan aktivitas berat } \\
\text { Pembatasan aktivitas } \\
\text { sangat berat }\end{array}$ & 0 & 0 \\
$\begin{array}{l}\text { Aktivitas terbatas di } \\
\text { tempat tidur }\end{array}$ & 0 & 0 \\
Total & 0 & 0 \\
\hline
\end{tabular}

Dari 43 perawat yang pernah mengalami keluhan NPB terdapat 39 perawat yang mengalami pembatasan aktivitas ringan, dan 4 perawat mengalami pembatasan aktivitas sedang.

\section{BAHASAN}

NPB adalah sindroma klinik yang ditandai dengan gejala utama nyeri atau perasaan lain yang tidak enak di daerah tulang punggung bagian bawah. ${ }^{1}$ Perawat merupakan tenaga kerja kesehatan yang berhubungan langsung dengan pasien, yang pekerjaannya dipengaruhi oleh berbagai faktor yang dapat menyebabkan penyakit akibat kerja seperti NPB. Berdasarkan tinjauan lebih dari 80 makalah tentang NPB pada perawat, setiap tahun angka kejadian NPB di dunia antara 40\%-50\%. Prevalensi lebih tinggi dilaporkan bahwa dari penelitian yang dilakukan di Turki didapatkan angka kejadian NPB pada perawat antara 62\%-88\%. ${ }^{8}$ Dalam penelitian ini dapat diketahui bahwa dari 50 perawat yang menjadi responden terdapat 43 perawat $(86 \%)$ yang pernah mengalami keluhan NPB.

Berdasarkan Tabel 1, dari 43 perawat yang pernah mengalami keluhan NPB terdapat 14 perawat $(32,5 \%)$ yang berjenis kelamin laki-laki, dan 29 perawat $(67,5 \%)$ berjenis kelamin perempuan. Hal ini sesuai dengan jumlah perawat yang bekerja di Irina F RSUP Prof. Dr. R. D. Kandou Manado dimana jumlah perawat berjenis kelamin perempuan memang lebih banyak dari perawat berjenis kelamin laki-laki sehingga karakteristik perawat laki-laki tidak terwakili. Hal ini serupa dengan yang dilaporkan Himawan ${ }^{9}$ pada perawat di RSUD Purbalingga yang mendapatkan hasil laki-laki sebanyak 14 orang (43,75\%), dan perempuan sebanyak 18 orang (56,52\%). Selain itu karena secara fisiologis, kemampuan otot perempuan memang lebih rendah daripada laki-laki sehingga daya tahan otot laki-laki lebih tinggi dibanding perempuan. ${ }^{10}$

Berdasarkan Tabel 1 dapat diketahui bahwa sebanyak 16 perawat $(37,2 \%)$ yang pernah mengalami keluhan NPB berusia 
antara 23-29 tahun, 19 perawat $(44,2 \%)$ berusia antara 30-39 tahun, 2 perawat (4,6\%) berusia antara 40-49 tahun, dan 6 perawat (14\%) berusia antara 50-57 tahun. Hal ini sesuai dengan teori yang menyebutkan bahwa sejalan dengan meningkatnya usia akan terjadi degenerasi pada tulang dan keadaan ini mulai terjadi di saat seseorang berusia 30 tahun yang berupa degenerasi jaringan. Hal tersebut menyebabkan stabilitas pada tulang dan otot menjadi berkurang. ${ }^{11}$ Kekuatan otot maksimal terjadi pada saat usia 20-29 tahun, selanjutnya terus terjadi penurunan sejalan dengan bertambahnya usia. ${ }^{12}$ Pada saat kekuatan dan ketahanan otot mulai menurun maka risiko terjadinya keluhan otot akan semakin meningkat. ${ }^{10}$ Hasil penelitian ini memperlihatkan perawat yang berusia lebih muda (kelompok usia 30-39 tahun) lebih banyak mengalami keluhan NPB dibanding perawat yang berusia lebih tua (kelompok usia 40-49 tahun dan 50-57 tahun). Hal ini dapat disebabkan oleh kemungkinan perawat yang berusia lebih muda memiliki beban kerja fisik yang lebih besar daripada perawat yang berusia lebih tua, misalnya dalam pekerjaan rumah tangga seperti mengurus anak yang masih kecil, karena perawat yang berusia lebih tua pasti memiliki anak yang sudah cukup dewasa dan mandiri. Selain itu perawat yang berusia lebih tua memiliki pangkat yang lebih tinggi sehingga beban kerja fisik dan jenis pekerjaan yang dilakukan pun berbeda dengan perawat yang berusia lebih muda, dimana pekerjaannya bisa dikatakan lebih berat secara fisik. Sama halnya dengan penelitian Sakinah ${ }^{13}$ pada pekerja batu bata di Kelurahan Lawawoi Kabupaten Sidrap dimana kategori usia yang paling banyak mengalami keluhan nyeri punggung bawah adalah responden yang berusia $>35$ tahun (51,9\%). Hal tersebut berbeda dengan hasil penelitian yang dilakukan Himawan ${ }^{9}$ pada perawat di RSUD Purbalingga yang menunjukkan bahwa responden yang mengalami keluhan NPB terbanyak (43,75\%) berusia 26-30 tahun.

Pekerja yang memiliki masa kerja $>5$ tahun memiliki risiko lebih besar menderita NPB dibanding dengan yang memiliki masa kerja $<5$ tahun. Hal ini dikarenakan pembebanan tulang belakang dalam waktu lama mengakibatkan rongga diskus menyempit dan menyebabkan degenerasi tulang belakang yang menyebabkan nyeri punggung bawah. ${ }^{14}$ Dalam penelitian ini dari jumlah 43 perawat yang pernah mengalami keluhan nyeri punggung bawah, 16 perawat $(37,2 \%)$ telah bekerja selama $<5$ tahun, sedangkan 27 perawat $(62,8 \%)$ telah bekerja selama> 5 tahun. Hal ini sesuai dengan hasil penelitian yang dilakukan oleh Sakinah ${ }^{13}$ pada pekerja batu bata di Kelurahan Lawawoi Kabupaten Sidrap yang menunjukkan responden dengan keluhan NPB paling banyak memiliki masa kerja $>5$ tahun (65,3\%). Masa kerja yang lama menyebabkan beban statik yang terus-menerus bila pekerja tidak memperhatikan faktor-faktor ergonomi dan akan lebih mudah menimbulkan keluhan NPB. ${ }^{15}$ Semakin lama masa kerja seseorang, semakin tinggi risiko untuk menderita NPB.

Lamanya seseorang bekerja sehari secara baik umumnya 6-8 jam. Memperpanjang waktu kerja lebih dari waktu tersebut biasanya mengakibatkan kecenderungan untuk timbulnya kelelahan, gangguan kesehatan termasuk keluhan NPB, angka absensi karena sakit meningkat dan dapat mengakibatkan penurunan produktivitas kerja. ${ }^{16}$ Dalam penelitian ini terdapat 7 perawat (16,3\%) yang bekerja selama <8 jam sehari, dan 36 perawat $(83,7 \%)$ bekerja selama $>8$ jam sehari. Hal ini sesuai dengan hasil penelitian yang dilakukan oleh Indri ${ }^{17}$ pada pekerja tekstil di bagian packing departemen spinning PT. $\mathrm{X}$ yang menunjukkan seluruh responden yang mengalami keluhan NPB ialah responden yang memiliki lama kerja $>8$ jam sehari yakni sebanyak 54 responden $(100 \%) .{ }^{17}$

Berdasarkan penilaian tingkat disabilitas atau keterbatasan aktivitas akibat NPB dengan menggunakan Modified Oswestry Low Back Pain Disability Questionnaire, terdapat 39 perawat 
(90,7\%) mengalami pembatasan aktivitas ringan, dan 4 perawat $(9,3 \%)$ mengalami pembatasan aktivitas sedang. Hasil penelitian menunjukkan paling banyak perawat memiliki pembatasan aktivitas ringan. Sesuai dengan penelitian yang dilakukan Yapar $^{15}$ pada tenaga kerja perusahaan pengelola the PT "X" di Kota Garut yang menunjukkan seluruh responden penelitian (30 responden) memiliki pembatasan aktivitas ringan. Hal tersebut menunjukkan bahwa seluruh tenaga kerja dapat melakukan aktivitas sehari-hari tanpa terganggu oleh NPB.

\section{SIMPULAN}

Dari hasil penelitian dan bahasan dapat disimpulkan bahwa mayoritas perawat yang bekerja di Irina F RSUP Prof. Dr. R. D. Kandou Manado pernah mengalami keluhan nyeri punggung bawah (NPB). Keluhan NPB lebih banyak dialami oleh perawat perempuan, kelompok usia 30-39 tahun, masa kerja $>5$ tahun, dan lama kerja $>8$ jam sehari.

Mayoritas perawat yang pernah mengalami keluhan NPB dapat melakukan aktivitas sehari-hari tanpa terganggu oleh rasa nyeri atau hanya mengalami pembatasan aktivitas ringan berdasarkan hasil penilaian dari Modified Oswestry Low Back Pain Disability Questionnaire.

\section{SARAN}

Untuk mengurangi keluhan NPB pada perawat dapat dilakukan tindakan seperti menggunakan sikap kerja yang ergonomis. Manajemen rumah sakit juga sebaiknya melakukan evaluasi terhadap aktivitas kerja perawat dengan postur atau sikap yang tidak ergonomis.

Selain itu untuk perawat dapat dilakukan olahraga untuk memelihara kelenturan dan kekuatan otot pinggang, serta latihan peregangan otot untuk mengurangi keluhan NPB.

Untuk perawat yang sering memperpanjang waktu kerja (lebih dari 1 shift sehari) disarankan untuk tetap bekerja sesuai dengan waktu yang ditentukan (1 shift sehari) sehingga lama paparan beban kerja berkurang dan dapat menurunkan resiko terjadinya nyeri punggung bawah.

Oleh karena kuesioner dalam penelitian ini masih terbatas, kiranya untuk penelitian selanjutnya mengenai karakteristik perawat yang mengalami keluhan NPB dapat ditambahkan beberapa pertanyaan mengenai faktor-faktor risiko NPB seperti jenis pekerjaan, sikap kerja dan postur tubuh saat bekerja, beban kerja fisik, IMT dan obesitas, merokok, riwayat trauma pada punggung, serta penggunaan sepatu bertumit tinggi pada saat bekerja.

\section{DAFTAR PUSTAKA}

1. Sunarto. Latihan pada Penderita Nyeri Punggung Bawah (3rd ed). Jakarta: Medika Jwalita, 2005.

2. Mahadewa TGB, Maliawan S. Diagnosis \& Tatalaksana Kegawat Daruratan Tulang Belakang (1st ed). Jakarta: CV Agung Seto, 2009; p. 156-88.

3. Daren PF, W Angus W, Sean PFH. Low Back Pain. 2008 Sep [cited 2015 Oct 2]. Available from: https://www.gov.uk/government/uplo ads/system/uploads/attachment_data/f ile/384519/low_back_pain.pdf

4. Anthony EC, David JA, Gregory PG, Andrew JH, Paul P, Connie JS, et al. Acute Low Back Pain. 2010 Jan [cited 2015 Oct 8]. Available from: http://www.med.umich.edu/1info/FH P/practiceguides/back/back.pdf

5. Taimela S, Kujala UM, Salminen JJ \& Viljanen T. The Prevalence of Low Back Pain among Children and Adolescents: A Nationwide, CohortBased Questionnaire Survey in Finland. Spine. 1997;22:1132-6.

6. Andersson GBJ. The Epidemiology of Spinal Disorders. In: Frymoyer JW, editor. The Adult Spine: Principles and Practice. Philadelphia: Lippincott-Raven, 1997; p. 93-141.

7. Tarwaka. Ergonomi Untuk Keselamatan, Kesehatan Kerja dan Produktivitas. Surakarta: UNIBA Press, 2004.

8. Azize K, Sultan K, Aysel A, Nevin D. Low Back Pain: Prevalence and Associated Risk Factors among Hospital Staff. Journal of Advanced Nursing. 2009;65(3):516-24.

9. Himawan F, Handoyo, Keksi GS. 
Hubungan Sikap dan Posisi Kerja dengan Low Back Pain pada Perawat di RSUD Purbalingga. The Soedirman Journal of Nursing. 2009;4(3):6.

10.Tarwaka, Solichul HAB, Lilik S. Ergonomi untuk Keselamatan, Kesehatan Kerja dan Produktivitas. Surakarta: UNIBA Press, 2004; p.. 119-21.

11.Bridger RS. Introduction to Ergonomics. Singapore: McGraww Hill Inc, 1995.

12.Batti'e MC, Bigos SJ, Fisher LD, Hansson TH, Jones ME, Wortley MD. Isometric Lifting as A Strength Predictor of Industrial Back Pain. Spine. 1989;14(8):851-6.

13.Sakinah, Rafael D. Furqaan N. Faktor yang Berhubungan dengan Keluhan Nyeri Punggung Bawah pada Pekerja Bongkar Muat Barang Pelabuhan Nusantara Kota Pare-pare tahun 2012.
(KTIS). Makassar: FKM Unhas: 2012.

14.Between L. Analisis Nyeri Punggung dengan Faktor-Faktor yang Berhubungan pada Pekerja Wanita di Penjahitan Pakaian PT X Gunung Putri Bogor Tahun 2005 [Tesis]. Jakarta: FKUI; 2005.

15.Yapar S. Prevalensi Low Back Pain pada Tenaga Kerja Perusahaan Pengolahan Teh PT. "X” di Kota Garut. (KTIS). Bandung: FK UK Maranatha; 2011.

16.Tarwaka, Solichul HAB, Lilik S. Ergonomi untuk Keselamatan, Kesehatan Kerja dan Produktivitas. Surakarta: UNIBA Press, 2004; p. 70.

17.Indri S. Kajian Manual Material Handling terhadap Kejadian Low Back Pain pada Pekerja Tekstil. 2013 [cited: 2016 Jan 20]. Available from: http://ejournal.undip.ac.id/index.php/j gti/article/viewFile/4775/432. 